\begin{tabular}{|c|l|}
\hline Title & Molecular Phy logeny of the Family Capitellidae (A nnelida) \\
\hline Author(s) & Tomioka, Shinri; Kakui, Keiichi; Kajihara, Hiroshi \\
\hline Citation & $\begin{array}{l}\text { Zoological Science, 35(5), 436-445 } \\
\text { https:/doi.org/40.2108/2s180009 }\end{array}$ \\
\hline Issue Date & 201810 \\
\hline Doc URL & http://hdl.handle.net/2115/75605 \\
\hline Type & article \\
\hline File Information & Zoological Science35-5_436-445(2018).pdf \\
\hline
\end{tabular}

Instructions for use 


\title{
Molecular Phylogeny of the Family Capitellidae (Annelida)
}

\author{
Shinri Tomioka ${ }^{1 *}$, Keiichi Kakui ${ }^{2}$, and Hiroshi Kajihara² \\ ${ }^{1}$ Rishiri Town Museum, Senhoshi, Rishiri Is., Hokkaido 097-0311, Japan \\ ${ }^{2}$ Department of Biological Sciences, Faculty of Science, Hokkaido University, \\ N10 W8, Sapporo, Hokkaido 060-0810, Japan
}

\begin{abstract}
Capitellids have emerged as monophyletic in most but not all recent molecular phylogenies, indicating that more extensive taxon sampling is necessary. In addition, monophyly of most or all capitellid genera was questionable, as some diagnostic characters vary ontogenetically within individuals. We tested the monophyly of Capitellidae and eight capitellid genera using phylogenetic analyses of combined 18S, 28S, $\mathrm{H3}$, and COI gene sequences from 36 putative capitellid species. In our trees, Capitellidae formed a monophyletic sister group to Echiura, and Capitella was also monophyletic, separated by a long branch from other capitellids. Well-supported clades each containing representatives of different genera, or containing a subset of species within a genus, indicated that Barantolla, Heteromastus, and Notomastus are likely not monophyletic. We mapped three morphological characters traditionally used to define capitellid genera (head width relative to width of first segment, number of thoracic segments, and number of segments with capillary chaetae) onto our tree. While Capitella showed unique character states, states in the other genera were decidedly not phylogenetically informative. Morphology-based capitellid taxonomy will require a fine-scale reevaluation of character states and detection of new characters.
\end{abstract}

Key words: Capitellida, capitellids, Scolecida, Sedentaria, systematics

\section{INTRODUCTION}

The family Capitellidae Grube, 1862 consists of freeliving, benthic, earthworm-like annelids and contains about 190 species (Rouse and Pleijel, 2001; Read, 2010). It includes Capitella teleta Blake, Grassle \& Eckelbarger, 2009, formerly known as "Capitella sp. I" (Grassle and Grassle, 1976), which is now used as a model annelid in the field of evolutionary developmental biology, and for which the complete genome has been sequenced (e.g., Ferrier, 2012; Seaver et al., 2012; Lauri et al., 2014; Seaver, 2016). Furthermore, some other species in the genus Capitella have been used as bioremediators of organically enriched sediments (e.g., Tsutsumi et al., 2005; Kinoshita et al., 2008) or environmental bioindicators of disturbed habitats (e.g., Reish, 1955; Grassle and Grassle, 1976; reviewed in Dean, 2008). While all capitellids are similar in external morphology, they have successfully colonized diverse environments. Although most species inhabit bottom substrata such as polluted sediments (e.g., Tsutsumi, 1987; Ahn et al., 1995; Méndez et al., 2001; Dean, 2008; Croquer et al., 2016), sandy beaches (e.g., Delgado et al., 2003; Incera et al., 2006; Papageorgiou et al., 2006; García-Garza and De León-González, 2011; Tomioka et al., 2012), and seagrass beds (e.g., Nakaoka et al., 2002; Omena and Creed, 2004; Eklöf et al., 2005; Tanner, 2005; Tomioka et al., 2013), some dwell among squid egg masses (e.g., Hartman, 1947), or burrow into molluscan shells (Blake, 1969) or whale bones

\footnotetext{
* Corresponding author. E-mail: shinri.tomioka@gmail.com doi:10.2108/zs180009
}

(e.g., Fujiwara et al., 2007; Amon et al., 2013; Silva et al., 2016; Sumida et al., 2016). Capitellidae is one of the few metazoan groups where some species exhibit poecilogony (e.g., Chia et al., 1996; Tsutsumi, 2005), or polymorphism in larval development, which has been reported only in some other polychaete groups (e.g., cirratulids, Petersen, 1999; spionids, David et al., 2014) and gastropod molluscs (e.g., Vedetti et al., 2012; McDonald et al., 2014). While capitellids are thus evolutionarily interesting, their phylogenetic relationships have scarcely been studied.

Since Eisig's (1887) extensive monograph on Capitellidae, this family has remained a taxonomically welldefined group (e.g., Hartman, 1947; Fauchald, 1977; Hutchings, 2000). In both morphology-based cladistic analyses (Rouse and Fauchald, 1997) and subsequent molecular analyses of annelid phylogeny (Bleidorn et al., 2003; Struck and Purschke, 2005; Rousset et al., 2007; Struck et al., 2007; Goto et al., 2013), Capitellidae has nearly always emerged as a monophyletic group (Fig. 1A-E). On the other hand, some 19th century naturalists (Carus, 1863; Malmgren, 1865; Haeckel, 1866; Quatrefages, 1866) did not regard Capitellidae as a group, and in Goto's (2016) multi-locus analysis of Echiura, the putative sister taxon to Capitellidae (Weigert et al., 2014), the four capitellid species included as outgroup taxa did not comprise a monophyletic group (Fig. $1 F)$, although the author himself suggested that this might have been the result of poor taxon sampling of capitellids. The monophyly of capitellids thus requires further testing with increased taxon sampling.

Capitellidae presently includes 44 genera (Fauchald, 1977; Piltz, 1977; McCammon and Stull, 1978; Rullier and 

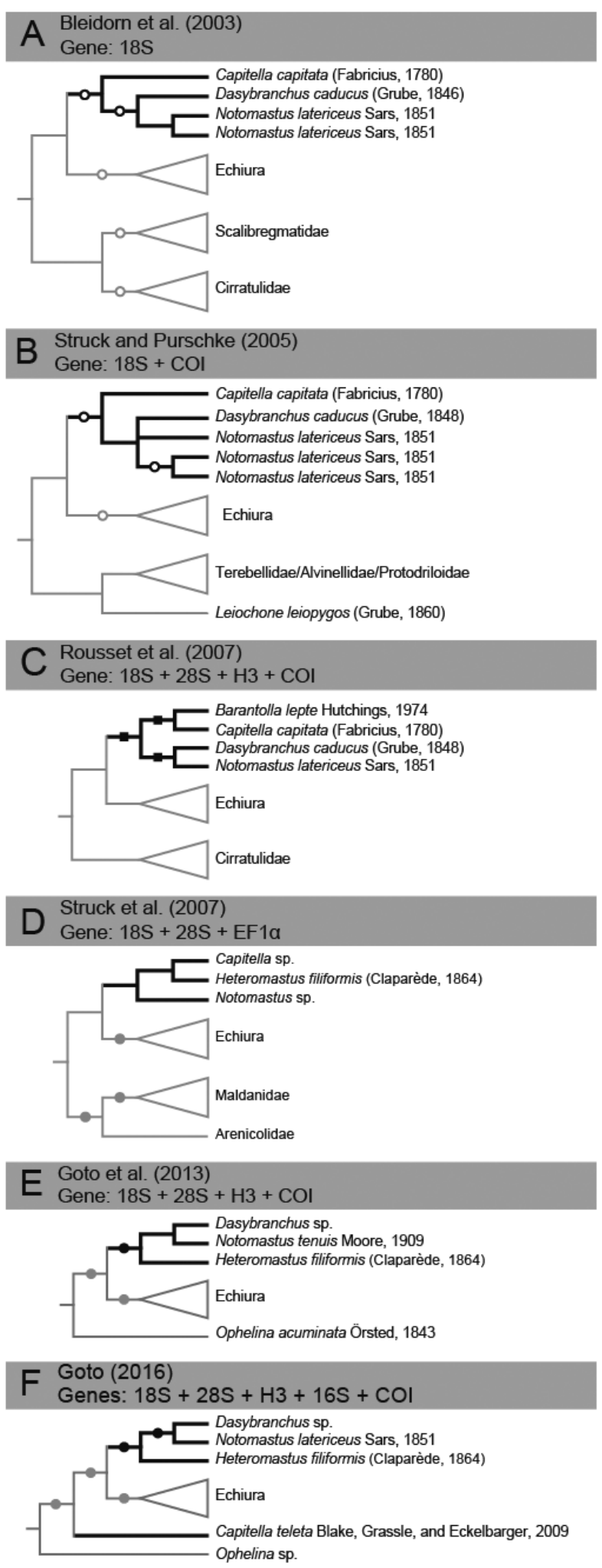

Fig. 1. (A-F) Partial tree topologies from selected, previous molecular studies that included more than two OTUs from Capitellidae. Nodes with open circles are supported with a bootstrap value (BS) greater than $90 \%$ in maximum-parsimony analyses and a posterior probability (PP) of 1.00 from Bayesian inference (BI). Nodes with solid circles are supported with a BS greater than $90 \%$ in maximum-likelihood analyses and 1.00 PP from BI. Nodes with solid squares are supported by a jackknife value greater than $90 \%$.
Amoureux, 1979; Amaral, 1980; Ewing, 1982; Amoureux, 1983; Kirkegaard, 1983; Brown, 1987; Garwood and Bamber, 1988; Warren, 1991; Capaccioni-Azzati and Martín, 1992; Warren and Parker, 1994; Blake, 2000; Buzhinskaja and Smirnov, 2000; Green, 2002; Magalhães and Bailey-Brock, 2012), most of which are likely not monophyletic, and among which phylogenetic relationships remain uninvestigated. Rouse and Pleijel (2001: p. 44) remarked, "the taxonomy of Capitellidae is in serious need of revision", because genera were, and still are, defined in a way that does not reflect phylogeny. Genera have been diagnosed based on unique combinations of morphological characters, such as the shape of the head, number of thoracic segments, arrangement/type of chaetae, presence or absence of branchiae, and shape of the pygidium (Fauchald, 1977; Blake et al., 2009). This 'unique combination' approach itself is unlikely to lead to monophyletic taxa (Sundberg, 1993; Sundberg and Pleijel, 1994), and one diagnostic character, the arrangement of chaetae, is known to change ontogenetically within individuals (Ewing, 1982; Fredette, 1982; George, 1984).

In this study, we conducted a molecular phylogenetic analysis of capitellid worms from Japanese waters to test the monophyly of Capitellidae and some of its constituent genera. This allowed us to also examine whether some of the generic diagnostic characters mentioned above are concordant with phylogenetic relationships.

\section{MATERIALS AND METHODS}

\section{Sampling and identification}

About 400 specimens of capitellid polychaetes were collected at 29 localities around Japan from 2012 to 2016 . The anterior portions of specimens were fixed in $10 \%$ formalin-seawater and later transferred into $70 \%$ ethanol for morphological observation; the posterior or middle portions were preserved in $99 \%$ ethanol for DNA extraction. DNA was extracted from a few individuals from each locality, and then molecularly barcoded using the genes $\mathrm{H} 3$ (nuclear histone $\mathrm{H} 3$ ), $18 \mathrm{~S}$ (nuclear 18S ribosomal RNA), and COI (mitochondrial cytochrome $c$ oxidase subunit I). From 42 specimens from which a sequence was obtained for at least one of these markers, 31 were selected to represent putative species (operational taxonomic units, or OTUs) to be included in analyses (Table 1). As outgroup taxa, one individual each of the maldanid Nicomache personata Johnson, 1901 (partially sequenced by Kajihara et al., 2014) and the naidid oligochaete Tubifex tubifex (Müller, 1774) (cultured by Professor Takashi Shimizu, Hokkaido University) were sequenced (Table 1). All specimens not destroyed for DNA extraction have been deposited in the Invertebrate Collection of the Hokkaido University Museum (ICHUM), Sapporo (Table 1).

Capitellid specimens were identified to the genus level based on combinations of the following five characters: $i$ ) width of the head relative to the first segment (Type $A$, head half the width of the first segment; Type B, head same width as first segment) (Fig. 2A, B); ii) number of thoracic segments; iii) arrangement/type of chaetae; iv) presence or absence of branchiae; and $v$ ) shape of the pygidium. The 31 specimens selected for analysis, each representing a single, putative species, were identified as representing eight genera (Table 2). Because most specimens were missing the posterior portion of the body upon collection, characters iv) and $v$ ) were not included in the character-state analysis. The first character (head type) was consistent irrespective of the state of the proboscis (i.e., whether it was extruded or retracted) or the degree of body contraction (ST pers. obs.). 
Table 1. List of specimens used in this study, with species name, sampling locality or source, habitat, DDBJ/ENA/GenBank accession numbers for $18 \mathrm{~S}, 28 \mathrm{~S}, \mathrm{H} 3$, and $\mathrm{CO}$ sequences, the museum catalogue number (ICHUM), and references.

\begin{tabular}{|c|c|c|c|c|c|c|c|c|}
\hline \multirow{2}{*}{ Species } & \multirow{2}{*}{$\begin{array}{c}\text { Sampling locality or } \\
\text { source }\end{array}$} & \multirow{2}{*}{ Habitat } & \multicolumn{4}{|c|}{ Accession number } & \multirow{2}{*}{$\begin{array}{l}\text { Catalogue } \\
\text { number }\end{array}$} & \multirow{2}{*}{ Reference } \\
\hline & & & $18 \mathrm{~S}$ & $28 S$ & $\mathrm{H} 3$ & $\mathrm{COI}$ & & \\
\hline \multicolumn{9}{|l|}{ Ingroup } \\
\hline Barantolla sp. 1 & $\begin{array}{c}\text { Muroran, Hokkaido } \\
\left(42.3049^{\circ} \mathrm{N}, 140.9885^{\circ} \mathrm{E}\right)\end{array}$ & seagrass bed & LC208025 & LC208055 & LC208087 & LC208116 & 5397 & this study \\
\hline Barantolla sp. 2 & $\begin{array}{c}\text { Oura Bay, Okinawa } \\
\left(26.5540^{\circ} \mathrm{N}, 128.0416^{\circ} \mathrm{E}\right)\end{array}$ & tidal mud flat & LC208026 & LC208056 & LC208088 & LC208117 & 5398 & this study \\
\hline $\begin{array}{l}\text { Capitella teleta Blake, } \\
\text { Grassle \& Eckelbarger, } \\
2009 \text { (1) }\end{array}$ & $\begin{array}{c}\text { Ainan, Ehime } \\
\left(32.9206^{\circ} \mathrm{N}, 132.5189^{\circ} \mathrm{E}\right)\end{array}$ & $\begin{array}{l}\text { muddy sediments } \\
\text { beneath aquaculture } \\
\text { rafts }\end{array}$ & LC208027 & LC208057 & LC208089 & LC120636 & 5167 & $\begin{array}{l}\text { Tomioka et al. } \\
\text { (2016), this study }\end{array}$ \\
\hline Capitella teleta 2 & GenBank & - & JF509728 & - & JF509713 & - & - & Andrade et al. (2011) \\
\hline Capitella aff. teleta & $\begin{array}{c}\text { Gamo, Miyagi } \\
\left(38.2578^{\circ} \mathrm{N}, 141.0144^{\circ} \mathrm{E}\right)\end{array}$ & tidal mud flat & LC208028 & LC208058 & LC208090 & LC120642 & 5130 & $\begin{array}{l}\text { Tomioka et al. } \\
\text { (2016), this study }\end{array}$ \\
\hline Capitella sp. 1 & $\begin{array}{c}\text { Monbetsu, Hokkaido } \\
\left(44.3645^{\circ} \mathrm{N}, 143.3546^{\circ} \mathrm{E}\right)\end{array}$ & seagrass bed & LC208029 & LC208059 & LC208091 & LC120651 & 5399 & $\begin{array}{l}\text { Tomioka et al. } \\
\text { (2016), this study }\end{array}$ \\
\hline Capitella sp. 2 & $\begin{array}{c}\text { Akkeshi, Hokkaido } \\
\left(43.0185^{\circ} \mathrm{N}, 144.8346^{\circ} \mathrm{E}\right)\end{array}$ & seagrass bed & - & LC208060 & - & LC208118 & 5400 & this study \\
\hline Capitella sp. 3 & $\begin{array}{c}\text { Onosato River, Osaka } \\
\left(34.3765^{\circ} \mathrm{N}, 135.2509^{\circ} \mathrm{E}\right)\end{array}$ & tidal mud flat & LC208030 & LC208061 & LC208092 & LC012038 & 5401 & this study \\
\hline Capitella sp. 4 & $\begin{array}{l}\text { Manko-Higata, Okinawa } \\
\left(26.1941^{\circ} \mathrm{N}, 127.6836^{\circ} \mathrm{E}\right)\end{array}$ & tidal mud flat & LC208031 & LC208062 & LC208093 & - & 5402 & this study \\
\hline Capitella sp. 5 & $\begin{array}{l}\text { Hatsukaichi, Hiroshima } \\
\left(34.2756^{\circ} \mathrm{N}, 132.2669^{\circ} \mathrm{E}\right)\end{array}$ & tidal mud flat & LC208032 & LC208063 & LC208094 & - & 5403 & this study \\
\hline Decamastus sp. 1 & $\begin{array}{l}\text { Hachi-Higata, Hiroshima } \\
\left(34.3260^{\circ} \mathrm{N}, 132.8979^{\circ} \mathrm{E}\right)\end{array}$ & tidal mud flat & LC208033 & LC208064 & LC208095 & - & 5404 & this study \\
\hline Decamastus sp. 2 & $\begin{array}{c}\text { off Manabe Island } \\
\left(34.3772^{\circ} \mathrm{N}, 133.6162^{\circ} \mathrm{E}\right)\end{array}$ & $\begin{array}{c}\text { unknown [a biological } \\
\text { dredge from the TR/V } \\
\text { Toyoshio-maru } \\
\text { (Hiroshima University)] }\end{array}$ & LC208034 & LC208065 & LC208096 & LC208119 & 5405 & this study \\
\hline Heteromastus sp. 1 & $\begin{array}{l}\text { Akkeshi Lake, Hokkaido } \\
\left(43.0515^{\circ} \mathrm{N}, 144.8568^{\circ} \mathrm{E}\right)\end{array}$ & tidal mud flat & LC208035 & LC208066 & LC208097 & LC208120 & 5406 & this study \\
\hline Heteromastus sp. 2 & $\begin{array}{l}\text { Hachi-Higata, Hiroshima } \\
\left(34.3260^{\circ} \mathrm{N}, 132.8979^{\circ} \mathrm{E}\right)\end{array}$ & tidal mud flat & LC208036 & LC208067 & LC208098 & LC208121 & 5407 & this study \\
\hline Heteromastus sp. 3 & $\begin{array}{c}\text { Nagura-Amparu, } \\
\text { Ishigaki Island, Okinawa } \\
\left(24.4007^{\circ} \mathrm{N}, 124.1407^{\circ} \mathrm{E}\right)\end{array}$ & tidal mud flat & LC208037 & LC208068 & LC208099 & LC208122 & 5408 & this study \\
\hline Heteromastus sp. 4 & $\begin{array}{c}\text { Sone-Higata, Fukuoka } \\
\left(33.8243^{\circ} \mathrm{N}, 130.9663^{\circ} \mathrm{E}\right)\end{array}$ & tidal mud flat & LC208038 & LC208069 & LC208100 & LC208123 & 5409 & this study \\
\hline Heteromastus sp. 5 & $\begin{array}{l}\text { Fushino River, Yamaguchi } \\
\left(34.0215^{\circ} \mathrm{N}, 131.4154^{\circ} \mathrm{E}\right)\end{array}$ & tidal mud flat & LC208039 & LC208070 & LC208101 & LC208124 & 5410 & this study \\
\hline Heteromastus sp. 6 & $\begin{array}{c}\text { Edo River, Tokyo } \\
\left(35.7007^{\circ} \mathrm{N}, 139.9252^{\circ} \mathrm{E}\right)\end{array}$ & tidal mud flat & - & LC208071 & LC208102 & LC208125 & 5411 & this study \\
\hline Heteromastus sp. 7 & $\begin{array}{c}\text { Manose River, Kagoshima } \\
\left(31.4487^{\circ} \mathrm{N}, 130.2949^{\circ} \mathrm{E}\right)\end{array}$ & tidal mud flat & LC208040 & LC208072 & LC208103 & LC208126 & 5412 & this study \\
\hline Heteromastus sp. 8 & $\begin{array}{c}\text { Koajiro-Higata, Kanagawa } \\
\left(35.1635^{\circ} \mathrm{N}, 139.6296^{\circ} \mathrm{E}\right)\end{array}$ & tidal mud flat & LC208041 & LC208073 & - & LC208127 & 5413 & this study \\
\hline $\begin{array}{l}\text { Heteromastus filiformis } \\
\text { (Claparède, 1864) }\end{array}$ & GenBank & - & DQ790081 & DQ790038 & - & - & - & Struck et al. (2007) \\
\hline Leiohrides sp. 1 & $\begin{array}{l}\text { Hachi-Higata, Hiroshima } \\
\left(34.3260^{\circ} \mathrm{N}, 132.8979^{\circ} \mathrm{E}\right)\end{array}$ & tidal mud flat & LC208042 & LC208074 & LC208104 & LC208128 & 5414 & this study \\
\hline Leiohrides sp. 2 & $\begin{array}{c}\text { Koajiro-Higata, Kanagawa } \\
\left(35.1635^{\circ} \mathrm{N}, 139.6296^{\circ} \mathrm{E}\right)\end{array}$ & tidal mud flat & LC208043 & LC208075 & LC208105 & - & 5415 & this study \\
\hline
\end{tabular}


Table 1. Continued.

\begin{tabular}{|c|c|c|c|c|c|c|c|c|}
\hline \multirow{2}{*}{ Species } & \multirow{2}{*}{$\begin{array}{c}\text { Sampling locality or } \\
\text { source }\end{array}$} & \multirow{2}{*}{ Habitat } & \multicolumn{4}{|c|}{ Accession number } & \multirow{2}{*}{$\begin{array}{l}\text { Catalogue } \\
\text { number }\end{array}$} & \multirow{2}{*}{ Reference } \\
\hline & & & $18 S$ & $28 S$ & $\mathrm{H} 3$ & $\mathrm{COI}$ & & \\
\hline Leiohrides sp. 3 & $\begin{array}{c}\text { Komi, Iriomote Island, } \\
\text { Okinawa } \\
\left(24.3511^{\circ} \mathrm{N}, 123.9381^{\circ} \mathrm{E}\right)\end{array}$ & $\begin{array}{l}\text { dead-coral debris } \\
\text { sediment on tidal flat }\end{array}$ & LC208044 & LC208076 & - & - & 5416 & this study \\
\hline Mastobranchus sp. 1 & $\begin{array}{c}\text { Komi, Iriomote Island, } \\
\text { Okinawa } \\
\left(24.3511^{\circ} \mathrm{N}, 123.9381^{\circ} \mathrm{E}\right)\end{array}$ & $\begin{array}{l}\text { dead-coral debris } \\
\text { sediment on tidal flat }\end{array}$ & LC208045 & - & LC208106 & LC208020 & 5417 & this study \\
\hline $\begin{array}{l}\text { Mediomastus } \\
\text { opertaculeus Tomioka, } \\
\text { Hiruta \& Kajihara, } 2013\end{array}$ & $\begin{array}{c}\text { Abashiri, Hokkaido } \\
\left(44.0493^{\circ} \mathrm{N}, 144.2596^{\circ} \mathrm{E}\right)\end{array}$ & seagrass bed & LC208046 & LC208077 & LC208107 & AB794985 & 4372 & $\begin{array}{l}\text { Tomioka et al. } \\
\text { (2013), } \\
\text { this study }\end{array}$ \\
\hline Notomastus sp. 1 & $\begin{array}{c}\text { Tama River, Tokyo } \\
\left(35.5411^{\circ} \mathrm{N}, 139.4401^{\circ} \mathrm{E}\right)\end{array}$ & tidal mud flat & LC208047 & LC208078 & LC208108 & LC208129 & 5424 & this study \\
\hline Notomastus sp. 2 & $\begin{array}{l}\text { Yagachi Island, Okinawa } \\
\left(26.6507^{\circ} \mathrm{N}, 128.0091^{\circ} \mathrm{E}\right)\end{array}$ & tidal mud flat & LC208048 & LC208079 & LC208109 & LC208130 & 5425 & this study \\
\hline Notomastus sp. 3 & $\begin{array}{c}\text { off Owase } \\
\left(34.1611^{\circ} \mathrm{N}, 136.8436^{\circ} \mathrm{E}\right)\end{array}$ & $\begin{array}{l}\text { unknown [a biological } \\
\text { dredge from the TR/V } \\
\text { Seisui-maru } \\
\text { (Mie University)] }\end{array}$ & LC208049 & LC208080 & LC208110 & - & 5426 & this study \\
\hline Notomastus sp. 4 & $\begin{array}{c}\text { Suou-Nada } \\
\left(33.7475^{\circ} \mathrm{N}, 131.5810^{\circ} \mathrm{E}\right)\end{array}$ & $\begin{array}{c}\text { unknown [a biological } \\
\text { dredge from the TR/V } \\
\text { Toyoshio-maru } \\
\text { (Hiroshima University)] }\end{array}$ & LC208050 & LC208081 & LC208111 & - & 5427 & this study \\
\hline Notomastus sp. 5 & $\begin{array}{l}\text { Torinoe-Higata, Okayama } \\
\left(34.4734^{\circ} \mathrm{N}, 133.5296^{\circ} \mathrm{E}\right)\end{array}$ & tidal mud flat & LC208051 & LC208082 & LC208112 & LC208131 & 5428 & this study \\
\hline Notomastus sp. 6 & $\begin{array}{c}\text { Takahashi River, } \\
\text { Okayama } \\
\left(34.5427^{\circ} \mathrm{N}, 133.7025^{\circ} \mathrm{E}\right)\end{array}$ & tidal mud flat & LC208052 & LC208083 & LC208113 & LC208132 & 5429 & this study \\
\hline Notomastus sp. 7 & $\begin{array}{c}\text { Fukiage Beach, } \\
\text { Kagoshima } \\
\left(31.4416^{\circ} \mathrm{N}, 130.2832^{\circ} \mathrm{E}\right)\end{array}$ & open sandy beach & LC208053 & LC208084 & LC208114 & - & 5430 & this study \\
\hline $\begin{array}{l}\text { Notomastus hemipodus } \\
\text { Hartman, } 1945\end{array}$ & $\begin{array}{c}\text { GenBank } \\
\text { (Bamfield, Canada) }\end{array}$ & - & HM746728 & - & HM746759 & - & - & Paul et al. (2010) \\
\hline $\begin{array}{l}\text { Notomastus latericeus } \\
\text { Sars, } 1851\end{array}$ & $\begin{array}{c}\text { GenBank } \\
\text { (Bohuslän, Sweden) }\end{array}$ & - & AY040697 & - & DQ779747 & - & - & $\begin{array}{l}\text { Siddall et al. (2001), } \\
\text { Rousett et al. (2007) }\end{array}$ \\
\hline $\begin{array}{l}\text { Notomastus tenuis } \\
\text { Moore, } 1909\end{array}$ & GenBank & - & DQ790084 & DQ790044 & - & - & - & Struck et al. (2007) \\
\hline \multicolumn{9}{|l|}{ Outgroup } \\
\hline Arhynchite hayaoi & & & & & & & & \\
\hline $\begin{array}{l}\text { Tanaka \& Nishikawa, } \\
2013\end{array}$ & GenBank & - & AB771462 & AB771474 & AB771487 & AB771495 & - & Goto et al. (2013) \\
\hline Bonellia sp. & GenBank & - & AB771463 & AB771475 & AB771488 & AB771496 & - & Goto (2016) \\
\hline Ikedosoma & & & & & & & & \\
\hline $\begin{array}{l}\text { gogoshimense lkeda, } \\
1904\end{array}$ & GenBank & - & AB967989 & AB968002 & AB968013 & AB968026 & - & Tanaka et al. (2014) \\
\hline $\begin{array}{l}\text { Listriolobus sorbillans } \\
\text { (Lampert, 1883) }\end{array}$ & GenBank & - & AB967995 & AB968006 & AB968019 & AB968032 & - & Tanaka et al. (2014) \\
\hline $\begin{array}{l}\text { Lumbricus polyphemus } \\
\text { (Fitzinger, 1833) }\end{array}$ & GenBank & - & HQ728904 & HQ728938 & - & - & - & $\begin{array}{l}\text { James and Davidson } \\
\qquad(2012)\end{array}$ \\
\hline $\begin{array}{l}\text { Nicomache personata } \\
\text { Johnson, } 1901\end{array}$ & $\begin{array}{c}\text { Oshoro Bay, Hokkaido } \\
\left(43.3639^{\circ} \mathrm{N}, 141.4317^{\circ} \mathrm{E}\right)\end{array}$ & seagrass bed & LC006051 & LC208085 & LC005496 & LC006052 & - & $\begin{array}{c}\text { Kajihara et al. (2014), } \\
\text { this study }\end{array}$ \\
\hline $\begin{array}{l}\text { Ophelina acuminata } \\
\text { Örsted, } 1843\end{array}$ & GenBank & - & DQ790085 & DQ790045 & HM746761 & - & - & Struck et al. (2007) \\
\hline $\begin{array}{l}\text { Tubifex tubifex } \\
\text { (Müller, 1774) }\end{array}$ & $\begin{array}{l}\text { Cultured by Professor } \\
\text { Takashi Shimizu }\end{array}$ & soft mud in a vat & LC208054 & LC208086 & LC208115 & LC208133 & 5431 & this study \\
\hline
\end{tabular}




\section{DNA extraction, PCR amplification, and sequencing}

Total DNA was extracted from the middle or posterior portion of worms with a DNeasy Blood \& Tissue Kit (Qiagen, Germany). Four regions [18S, 28S (nuclear 28S rRNA), H3, and COI] were sequenced for the 31 capitellid and two outgroup species. Primers used for PCR amplification and sequencing are listed in Table 3. Based on the sequence of Mediomastus opertaculeus Tomioka, Hiruta \& Kajihara, 2013, a specific primer (Mastus_COI_F) was designed by using Primer3Plus (Rozen and Skaletsky, 2000). PCRs were performed with an iCycler thermal cycler (BioRad, USA) in $10-\mu$ reaction volumes each containing $1 \mu \mathrm{l}$ of total DNA template, $1 \mu \mathrm{l}$ of $10 \times$ Ex Taq buffer (TaKaRa Bio, Japan), $2 \mathrm{mM}$ each dNTP, $1 \mu \mathrm{M}$ each primer, and $0.25 \mathrm{U}$ of TaKaRa Ex Taq DNA polymerase ( $5 \mathrm{U} / \mu \mathrm{l}$; TaKaRa Bio) in deionized water. PCR conditions were $95^{\circ} \mathrm{C}$ for $90 \mathrm{~s} ; 35$ cycles of $95^{\circ} \mathrm{C}$ for $30 \mathrm{~s}, 50^{\circ} \mathrm{C}$ for $30 \mathrm{~s}$, and $72^{\circ} \mathrm{C}$ for $1 \mathrm{~min}\left(\mathrm{COI}, \mathrm{H} 3\right.$ ) or $2 \mathrm{~min}(18 \mathrm{~S}, 28 \mathrm{~S})$; and $72^{\circ} \mathrm{C}$ for $7 \mathrm{~min}$. PCR products were purified following the method of Boom et al. (1990) with some modifications (Kobayashi et al., 2009). Terminator reactions were done with a BigDye Terminator ver. 3.1 Cycle Sequencing Kit (Life Technologies, USA) following the manufacturer's protocol. Sequencing was performed with a 3730 DNA Analyzer (Applied Biosystems, USA). Sequences were checked and assembled by using MEGA ver. 5.2.2 (Tamura et al., 2011). They have been deposited in the DDBJ/ENA/GenBank databases under accession numbers LC012038 and LC208025-LC208133. In addition, our dataset contained 37 sequences downloaded from public databases (Table 1).

\section{Phylogenetic tree construction}

To reconstruct phylogeny, we analyzed a combined dataset (18S, 28S, H3, and COI) using maximum likelihood (ML) and Bayesian inference $(\mathrm{BI})$. The outgroup, augmented with additional taxa chosen by reference to recent annelid phylogenomic studies (Struck et al., 2011, 2015; Weigert et al., 2014), contained eight species representing Sedentaria. Sequences were aligned by using MAFFT ver. 7 (Katoh and Standley, 2013) under the options E-INS$i$ for $18 \mathrm{~S}$ and $28 \mathrm{~S}$, and Auto for $\mathrm{H} 3$ and COI. trimAl ver. 1.2 (CapellaGutiérrez et al., 2009) was used to remove poorly aligned regions (18S, 693 bases including indels; 28S, 441 bases including indels; $\mathrm{COI}$, six bases including indels; $\mathrm{H} 3$, five bases) with the strict option. The aligned dataset of 44 species (36 ingroup capitellids and 8 outgroup taxa) comprised $18 \mathrm{~S}$ (1250 bases including indels), $28 \mathrm{~S}$ (576 bases including indels), H3 (317 bases without indels), and COI (529 bases including indels).

For the ML analysis, the partition method implemented in RAxML ver. 8.0 (Stamatakis, 2014) was used with the GTR + G substitution model; nodal support values were obtained through ML analyses of 1000 bootstrap pseudoreplicates (Felsenstein, 1985; Tavaré, 1986). For the $\mathrm{BI}$ analysis, MrBayes ver. 3.1.2 (Ronquist and Huelsenbeck, 2003) was used with the following substitution models selected by PartitionFinder ver. 1.1.1 (Lanfear et al., 2012) for the partitions: K80 + $\mathrm{I}+\mathrm{G}$ for $18 \mathrm{~S}$ and $\mathrm{H} 3$ (first and third codon positions); GTR + G for 28S; HKY + I + G for $\mathrm{H} 3$ (second codon position) and COI (first and second codon positions); and GTR + I + $\mathrm{G}$ for COI (third codon position). A Markov chain Monte Carlo analysis (MCMC) was simulated for 10 million generations and sampled every 100 generations. The first $25 \%$ of the trees were discarded as burn-in. The trace files generated by the MCMC runs were inspected in Tracer ver. 1.6.0 (Rambaut
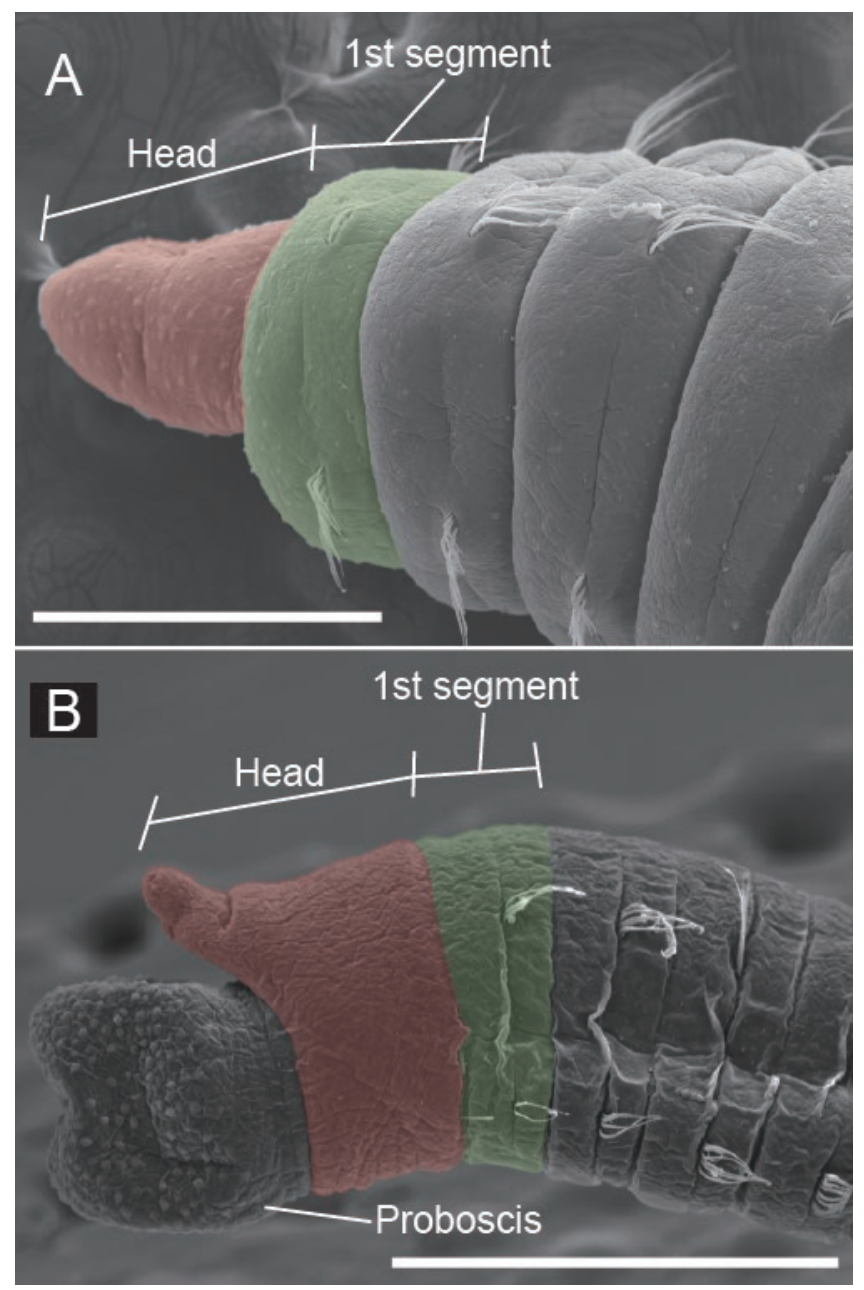

Fig. 2. SEM images showing the two types of head in Capitellidae, with the boundary between the head and first segment labeled. (A) Capitella teleta (Type A). (B) Mediomastus opertaculeus (Type B); the width ratio between the head and first segment is constant even when the proboscis is retracted. Scale bars: $1 \mathrm{~mm}$.

Table 2. List of selected morphological character states of capitellid genera in this study. For shape of the head: A, head half the width of first segment; $B$, head same width as first segment. Asterisk $\left(^{*}\right)$ indicates abdominal segments with some pairs of fascicles including both capillary chaetae and hooded hooks on dorsal side.

\begin{tabular}{|c|c|c|c|c|c|}
\hline Genus & $\begin{array}{l}\text { Number of } \\
\text { thoracic } \\
\text { segments }\end{array}$ & $\begin{array}{c}\text { Number of } \\
\text { segments with } \\
\text { capillary chaetae }\end{array}$ & $\begin{array}{l}\text { Presence or } \\
\text { absence of } \\
\text { branchiae }\end{array}$ & $\begin{array}{l}\text { Shape of the } \\
\text { pygidium }\end{array}$ & $\begin{array}{l}\text { Shape of } \\
\text { the head }\end{array}$ \\
\hline Barantolla & 11 & 6 & unknown & unknown & B \\
\hline Capitella & 9 & 7 or 9 & $\begin{array}{l}\text { absent or } \\
\text { unknown }\end{array}$ & $\begin{array}{l}\text { without } \\
\text { appendages } \\
\text { or unknown }\end{array}$ & A \\
\hline Decamastus & 10 & 10 & unknown & unknown & B \\
\hline Heteromastus & 11 & 5 & unknown & unknown & B \\
\hline Leiochrides & 12 & 12 & present & unknown & B \\
\hline Mastobranchus & 11 & $11^{*}$ & unknown & unknown & B \\
\hline Mediomastus & 10 & 4 & absent & $\begin{array}{l}\text { with a caudal } \\
\text { cirrus }\end{array}$ & B \\
\hline Notomastus & 11 & 11 & unknown & unknown & B \\
\hline
\end{tabular}


Table 3. List of PCR and cycle sequencing primers used in this study with genes, primer names, sequences, and references.

\begin{tabular}{|c|c|c|c|}
\hline Gene & Primer name & Sequence $\left(5^{\prime}\right.$ to $\left.3^{\prime}\right)$ & Reference \\
\hline \multirow[t]{6}{*}{$18 \mathrm{~S}$} & $\mathrm{~F} 1$ & TACCTGGTTGATCCTGCCAG & Yamaguchi and Endo (2003) \\
\hline & $\mathrm{F} 2$ & CCTGAGAAACGGCTRCCACAT & Yamaguchi and Endo (2003) \\
\hline & $\mathrm{F} 4$ & GGTCTGTGATGCCCTYAGATGT & Yamaguchi and Endo (2003) \\
\hline & R6 & TYTCTCRKGCTBCCTCTCC & Yamaguchi and Endo (2003) \\
\hline & R8 & ACATCTRAGGGCATCACAGACC & Yamaguchi and Endo (2003) \\
\hline & R9 & GATCCTTCCGCAGGTTCACCTAC & Yamaguchi and Endo (2003) \\
\hline \multirow[t]{4}{*}{$28 \mathrm{~S}$} & LSU5 & ACCCGCTGAAYTTAAGCA & Littlewood (1994) \\
\hline & LSU3 & TCCTGAGGGAAACTTCGG & Littlewood (1994) \\
\hline & $\mathrm{D} 2 \mathrm{f}$ & CTTTGAAGAGAGAGTTC & Littlewood (1994) \\
\hline & $28 Z$ & CTTGGTCCGTGTTTCAAGAC & Hillis and Dixon (1991) \\
\hline \multirow[t]{2}{*}{$\mathrm{H} 3$} & $\mathrm{aF}$ & ATGGCTCGTACCAAGCAGAC & Colgan et al. (1998) \\
\hline & aR & ATATCCTTRGGCATRATRGTGAC & Colgan et al. (1998) \\
\hline \multirow[t]{7}{*}{$\mathrm{COI}$} & LCO 1490 & GGTCAACAAATCATAAAGATATTGG & Folmer et al. (1994) \\
\hline & HCO 2198 & TAAACTTCAGGGTGACCAAAAAATCA & Folmer et al. (1994) \\
\hline & polyLCO & GAYTATWTTCAACAAATCATAAAGATATTGG & Carr et al. (2011) \\
\hline & polyHCO & TAMACTTCWGGGTGACCAAARAATCA & Carr et al. (2011) \\
\hline & Cap_COI_F & GGAATTTGAGGTGGGCTTGT & Tomioka et al. (2016) \\
\hline & Cap_COI_R & CACCACCACCAGTATTATCA & Tomioka et al. (2016) \\
\hline & Mastus_COI_R & AAGTACGGGGTCTCCWCCWC & this study \\
\hline
\end{tabular}

et al., 2014) to check whether the number of sampling generations and effective sample sizes (ESS) were large enough for reliable parameter estimates.

\section{RESULTS}

\section{Phylogenetic analyses}

The $\mathrm{ML}$ and $\mathrm{BI}$ trees were identical, with some differences at poorly supported terminal nodes; only the ML tree is shown here (Fig. 3). In the trees, Capitellidae is monophyletic, with nodal support of 98/1.00 (BS/PP), and forms the sister group to echiurans (93/1.00) (Fig. 3). Within Capitellidae, four clades appeared in both trees and had relatively high nodal support (greater than $95 \% \mathrm{BS}$ and $1.00 \mathrm{PP})$. Clade 1 (100/1.00) includes all OTUs identified as Capitella and is separated from the sister clade by a long

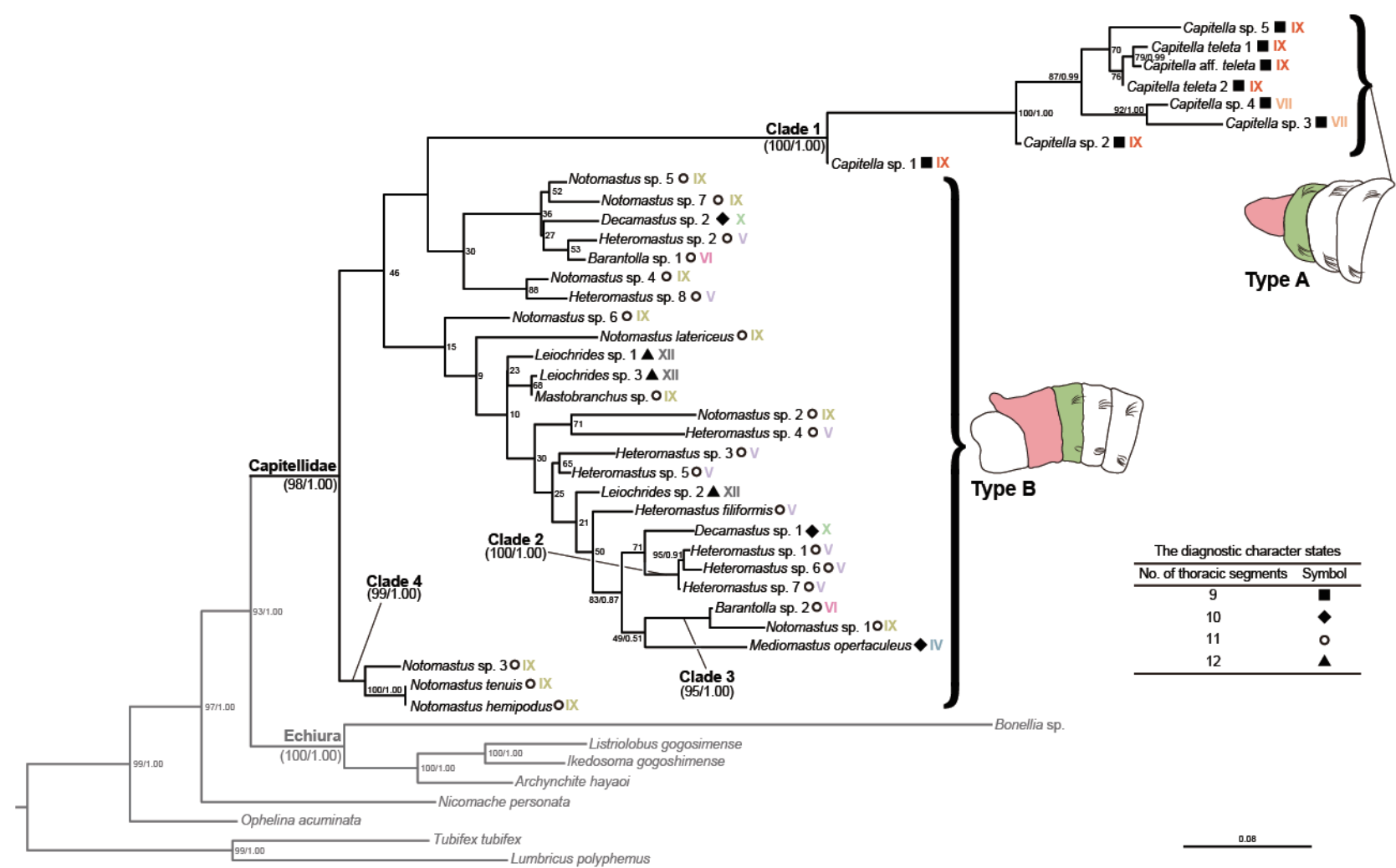

Fig. 3. Maximum-likelihood tree based on a combined dataset of $18 \mathrm{~S}, 28 \mathrm{~S}, \mathrm{H} 3$, and $\mathrm{CO}$ gene sequences. Numbers near nodes indicate the maximum-likelihood bootstrap support value in percent and posterior probability from Bayesian inference. Clades with both values shown at the basal node were congruent between the ML and BI trees. Clades with only the bootstrap value were not congruent between the two analyses. The number of thoracic segments is indicated by symbols (see the key at right), and the number of segments with capillary chaetae is indicated by roman numerals. 
branch; Clade 2 (100/1.00) contains Heteromastus spp. 1, 6, and 7; Clade 3 (95/1.00) consists of Barantolla sp. 2 and Notomastus sp. 1; and Clade 4 (99/1.00) contains Notomastus tenuis Moore, 1909, Notomastus hemipodus Hartman, 1945, and Notomastus sp. 3. Other nodes in Capitellidae were poorly supported, with values lower than 90\% BP and 0.99 PP (Fig. 3).

\section{Distribution of diagnostic characters}

Figure 3 shows the distribution on the ML tree of the states of three key characters that have been used to diagnose capitellid genera: $i$ ) head shape, ii) number of thoracic segments; and iii) arrangement/type of chaetae. Clade 1 (exclusively comprising Capitella) is clearly distinct in that all the constituent members uniquely have the Type-A head and nine thoracic segments; the number of segments with capillary chaetae is either seven or nine, states not found in other capitellid OTUs included in the analysis.

No character states were found to be unique to or specific for the rest of the clades, all of which, however, have the Type-B head. The OTUs in Clades 2 and 4 share the same states for the three characters, but, again, these are not clade-specific. Barantolla sp. 2 and Notomastus sp. 1 in Clade 3 both have 11 thoracic segments, but this character state also occurs in many other OTUs included in the analysis.

\section{DISCUSSION}

The expanded taxon sampling in our study supports the monophyly of Capitellidae, in agreement with several previous phylogenetic studies (e.g., Bleidorn et al., 2003; Struck and Purschke, 2005). The non-monophyly of Capitellidae in Goto (2016) may be attributable to inadequate taxon sampling (e.g., Hillis, 1998; Zwickl and Hillis, 2002) of Capitellidae or by different gene markers having been used in the analyses.

Most nodes except Clade 1 in our trees were weakly supported, and a better-supported tree might show a higher degree of OTUs forming clades by genus. However, a wellsupported clade (Clade 3, Fig. 3) contained OTUs representing different genera, indicating that at least the genera Barantolla and Notomastus (and possibly also Heteromastus) are not monophyletic as currently diagnosed. Except for Capitella, three of the morphological characters traditionally used in defining capitellid genera (head type; number of thoracic segments; number of segments with capillary chaetae) are not informative for the purpose of delineating genera as natural groups.

Our results suggest that Capitella is monophyletic (Clade 1, Fig. 3). The implication of the monophyly of Capitella is that it should form the basis for research to illustrate evolutionary histories of habitat expansion [e.g., sand interstices (Green, 2002), whale bones (Silva et al., 2016), and squid mass egg (Hartman, 1947)], diversification of larval developmental forms [lecithotrophy, planktotrophy (Blake et al., 2009), and poecilogony (e.g., Chia et al., 1996; Tsutsumi, 2005)], and other interesting features found in this genus.

To better resolve relationships within Capitellidae, broader taxon sampling and additional genetic markers will both be necessary. If there is to be any hope of identifying capitellid genera as natural groups based on morphology, the morphological characters traditionally used in defining genera will require a fine-scale reexamination, and new characters must be sought. In addition, future analyses including species showing specialized features as mentioned above will illustrate character evolution in Capitella.

\section{ACKNOWLEDGMENTS}

We thank Katsutoshi Ito, Naoto Jimi, Taeko Kimura, Shoichi Kimura, Susumu Ohtsuka, and Takashi Shimizu for providing specimens; Captains Makoto Uchida of TRV Seisui-maru, Kazumitsu Nakaguchi of TRV Toyoshio-maru, and the crews and researchers on the two vessels for support during cruises; So Ishida, Kiyotaka Hatooka, Takeshi Nakajo, Yusuke Suda, Daisuke Uyeno, and Hiroshi Yamasaki for organizing surveys; Hiromitsu Era, Hisanori Kohtsuka, Tohru Naruse, Shin Nishihira, and Koji Shibazaki for assistance in sampling; the participants in the field trip to Okayama for assistance in sampling; Masahiro Nakaoka, Waka Sato-Okoshi, and the staffs of the Iriomote Station, Akkeshi Marine Station, Takehara Marine Science Station for providing laboratory facilities; Yuanning Li for advice on phylogenetic analysis; Matthew H. Dick for critically revising our manuscript; and the members of the Biodiversity I Laboratory (Department of Natural History Sciences, Hokkaido University) for support in various ways. This work is part of the results from the field workshops "Umisawakai" in Okinawa and "Wakate-polychaetologists" in Misaki.

\section{COMPETING INTERESTS}

This work was supported by the Japan Society for the Promotion of Science (JSPS) (Grant Numbers JP16J00388 and JP24240113); the Research Institute of Marine Invertebrates (FY2013); the Tropical Biosphere Research Center, University of the Ryukyus, as Collaborative Research (FY2014); the Fujiwara Natural History Foundation (FY2015); and the Japan Marine Association for Marine Biology (JAMBIO; No. 27-56).

\section{AUTHOR CONTRIBUTIONS}

ST designed the study, did morphological observation, performed experiments and analyzed the data. All authors wrote the manuscript. All authors read and approved the final manuscript.

\section{REFERENCES}

Ahn IY, Kang YC, Choi JW (1995) The influence of industrial effluents on intertidal benthic communities in Panweol, Kyeonggi Bay (Yellow Sea) on the west coast of Korea. Mar Pollut Bull 30: 200-206

Amaral ACZ (1980) Breve caracterização dos gêneros da família Capitellidae Grube (Annelida, Polychaeta) e descrição de Nonatus longilineus gen. sp. nov. Bol Inst Oceanogr 29: 99-106

Amon DJ, Glover AG, Wiklund H, Marsh L, Linse K, Rogers AD, et al. (2013) The discovery of a natural whale fall in the Antarctic deep sea. Deep-Sea Res part II Top Stud Oceanogr 92: 87-96

Amoureux L (1983) Annélides polychètes du golfe d'Aqaba (mer Rouge). Description d'un genre nouveau et de deux espèces nouvelles. Bull Mus Natl Hist Nat Paris Sér 4 5: 723-742

Andrade SCS, Strand M, Schwartz M, Chen H, Kajihara H, Döhren $\mathrm{J}$, et al. (2011) Disentangling ribbon worm relationships: multilocus analysis supports traditional classification of the phylum Nemertea. Cladistics 27: 1-19

Blake JA (1969) Systematics and ecology of shell-boring polychaetes from New England. Am Zool 9: 813-820

Blake JA (2000) Family Capitellidae Grube, 1862. In "Taxonomic Atlas of the Benthic Fauna of the Santa Maria Basin and Western Santa Barbara Channel. Volume 7 of 14. The Annelida Part 4. Polychaeta: Flabelligeridae to Sternaspidae" Ed by JA 
Blake, B Hilbig, PV Scott, Santa Barbara Museum of Natural History, Santa Barbara, pp 47-96

Blake JA, Grassle JP, Eckelbarger KJ (2009) Capitella teleta a new species designation for the opportunistic and experimental Capitella sp. I, with a review of the literature for confirmed record. Zoosymposia 2: 25-53

Bleidorn C, Vogt L, Bartolomaeus T (2003) New insight into polychaete phylogeny (Annelida) inferred from 18S rDNA sequences. Mol Phylogenet Evol 29: 279-288

Boom R, Sol CJA, Salimans MMM, Jansen CL, Wertheim-Van Dillen PME, Van der Noordaa J (1990) Rapid and simple method for purification of nucleic acids. $\mathrm{J}$ Clin Microbiol 28: 495-503

Brown B (1987) A new genus and species of Capitellidae (Polychaeta) from the Atlantic coast of the United States. Bull Biol Soc Wash 7: 56-61

Buzhinskaja GN, Smirnov RV (2000) Abyssocapitella commensalis gen. et sp. $\mathrm{n}$. associated with the deep-sea pogonophore Spirobrachia leospira Gureeva, 1975 (Polychaeta: Capitellidae). Ophelia 52: 171-176

Capaccioni-Azzati R, Martín D (1992) Pseudomastus deltaicus gen. et sp. n. (Polychaeta: Capitellidae) from a shallow water bay in the North-Western Mediterranean Sea. Zool Scripta 21: 247-250

Capella-Gutiérrez S, Silla-Martínez JM, Gabaldón T (2009) trimAl: a tool for automated alignment trimming in large-scale phylogenetic analyses. Bioinformatics 25: 1972-1973

Carr CM, Hardy SM, Brown TM, Macdonald TA, Hebert DNP (2011) A tri-oceanic perspective: DNA barcoding reveals geographic structure and cryptic diversity in Canadian polychaetes. PLoS ONE 6: e22232

Carus JV (1863) Vermes. In "Handbuch der Zoologie" Ed by WCH Peters, JV Carus, CEA Gerstaecker, Wilhelm Engelmann, Leipzig, pp 422-484

Chia FS, Gibson G, Qian PY (1996) Poecilogony as a reproductive strategy of marine invertebrates. Oceanol Acta 19: 203-208

Colgan DJ, McLauchlan A, Wilson GDF, Livingston SP, Edgecombe GD, Macaranas J, et al. (1998) Histone H3 and U2 snRNA DNA sequences and arthropod molecular evolution. Aust J Zool 46: $419-437$

Croquer A, Bone D, Bastidas C, Ramos R, García E (2016) Monitoring coastal pollution associated with the largest oil refinery complex of Venezuela. PeerJ 4: e2171

David AA, Matthee CA, Simon CA (2014) Poecilogony in Polydora hoplura (Polychaeta: Spionidae) from commercially important molluscs in South Africa. Mar Biol 161: 887-898

Dean HK (2008) The use of polychaetes (Annelida) as indicator species of marine pollution: a review. Rev Biol Trop 56: 11-38

Delgado JD, Núñez J, Riera R, Monterroso Ó (2003) Abundance and diversity patterns of annelids from intertidal sandy beaches in Iceland. Hydrobiologia 496: 311-319

Eisig H (1887) Monographie der Capitelliden des Golfes von Neapel und der angrenzenden Meeres-abschnitte: nebst Untersuchungen zur vergleichenden Anatomie und Physiologie. Fauna Flora Golfes Neapel Angrenzenden Meeres-Abschnitte 16: xxi $+1-906$

Eklöf JS, Torre-Castro M de la, Adelsköld L, Jiddawi NS, Kautsky N (2005) Differences in macrofaunal and seagrassblages in seagrass beds with and without seaweed farms. Estuar Coast Shelf Sci 63: 385-396

Ewing RM (1982) A partial revision of the genus Notomastus (Polychaeta: Capitellidae) with a description of a new species from the Gulf of Mexico. Proc Biol Soc Wash 95: 232-237

Fauchald K (1977) The polychaete worms. Definitions and keys the orders, families and genera. Nat Hist Mus Los Angeles City Sci Ser 28: 1-188

Felsenstein J (1985) Confidence limits on phylogenies: an approach using the bootstrap. Evolution 39: 783-791

Ferrier DEK (2012) Evolutionary crossroads in developmental biology: annelids. Development 139: 2643-2653

Folmer O, Black M, Hoeh W, Lutz R, Vrijenhoek R (1994) DNA primers for amplification of mitochondrial cytochrome $c$ oxidase subunit I from diverse metazoan invertebrates. Mol Mar Biol Biotechnol 3: 294-299

Fredette TJ (1982) Evidence of ontogenetic setal changes in Heteromastus filiformis (Polychaeta: Capitellidae). Proc Biol Soc Wash 95: 194-197

Fujiwara Y, Kawato M, Yamamoto T, Yamanaka T, Sato-Okoshi W, Noda C, et al. (2007) Three-year investigations into sperm whale-fall ecosystem in Japan. Mar Ecol 28: 219-232

García-Garza ME, De León-González JA (2011) Review of the Capitellidae (Annelida, Polychaeta) from the Eastern Tropical Pacific region, with notes on selected species. ZooKeys 151: $17-52$

Garwood PR, Bamber RN (1988) A new genus and species of capitellid polychaete from Northeast England. Ophelia 29: 119-126

George JD (1984) The behavior and life history of a mangrovedwelling capitellid (Polychaeta). In "Proceedings of the First International Polychaeta Conference, Sydney" Ed by PA Hutchings, The Linnean Society of New South Wales, Sydney, pp 323-337

Goto R (2016) A comprehensive molecular phylogeny of spoon worms (Echiura, Annelida): Implications for morphological evolution, the origin of dwarf males, and habitat shifts. Mol Phylogenet Evol 99: 247-260

Goto R, Okamoto T, Ishikawa H, Hamamura Y, Kato M (2013) Molecular phylogeny of echiuran worms (Phylum: Annelida) reveals evolutionary pattern of feeding mode and sexual dimorphism. PLOS ONE 8: e56809

Grassle JP, Grassle JF (1976) Sibling species in the marine pollution indicator Capitella (Polychaeta). Science 192: 567-569

Green K (2002) Capitellidae (Polychaeta) from the Andaman Sea. Phuket Mar Biol Cent Res Bull 24: 249-343

Haeckel E (1866) Allgemeine Entwickelungsgeschichte der Organismen, kritische Grundzüge der mechanischen Wissenschaft von den entstehenden Formen der Organismen, begründet durch die Descendenz-Theorie. Georg Reimer, Berlin

Hartman O (1947) Polychaetous annelids. Part VII. Capitellidae. Allan Hancock Pac Exped 10: 391-480

Hillis DM (1998) Taxonomic sampling, phylogenetic accuracy, and investigator bias. Syst Biol 47: 3-8

Hillis DM, Dixon MT (1991) Ribosomal DNA: molecular evolution and phylogenetic inference. Q Rev Biol 66: 411-453

Hutchings PA (2000) Family Capitellidae. In "Polychaetes \& Allies: The Southern Synthesis. Fauna of Australia. Vol. 4A Polychaeta, Myzostomida, Pogonophora, Echiura, Sipuncula" Ed by PL Beesley, GJB Ross, CJ Glasby, CSIRO Publishing, Melbourne, pp 67-72

Incera M, Lastra M, López J (2006) Effect of swash climate and food availability on sandy beach macrofauna along the NW coast of the Iberian Peninsula. Mar Ecol Prog Ser 314: 25-33

James SW, Davidson SK (2012) Molecular phylogeny of earthworms (Annelida: Crassiclitellata) based on 28S, 18S and 16S gene sequences. Invertebr Syst 26: 213-229

Kajihara H, Tomioka S, Kakui K, Iseto T (2014) Phylogenetic position of the queer, backward-bent entoproct Loxosoma axisadversum (Entoprocta: Solitaria: Loxosomatidae). Spec Div 20: 83-88

Katoh K, Standley DM (2013) MAFFT multiple sequence alignment software version 7: improvements in performance and usability. Mol Biol Evol 30: 772-780

Kinoshita K, Tamaki S, Yoshioka M, Srithonguthai S, Kunihiro T, Hama D, et al. (2008) Bioremediation of organically enriched 
sediment deposited below fish farms with artificially masscultured colonies of a deposit-feeding polychaete Capitella sp. I. Fish Sci 74: 77-87

Kirkegaard JB (1983) Bathyal benthic polychaetes from the N.E. Atlantic Ocean, S.W. of the British Isles. J Mar Biol Assoc UK 63: 593-608

Kobayashi N, Ohta Y, Katoh T, Kahono S, Hartini S, Katakura H (2009) Molecular phylogenetic analysis of three groups of Asian epilachnine ladybird beetles recognized by the female internal reproductive organs and modes of sperm transfer. $J$ Nat Hist 43: 1637-1649

Lanfear R, Calcott B, Ho SYW, Guindon S (2012) PartitionFinder: combined selection of partitioning schemes and substitution models for phylogenetic analyses. Mol Biol Evol 29: 1695-1701

Lauri A, Brunet T, Handberg-Thorsager M, Fischer AHL, Simakov O, Steinmetz PRH, et al. (2014) Development of the annelid axochord: insights into notochord evolution. Science 345 : 1365-1368

Littlewood DTJ (1994) Molecular phylogenetics of cupped oysters based on partial 28S rRNA gene sequences. Mol Phylogenet Evol 3: 221-229

Magalhães WF, Bailey-Brock JH (2012) Capitellidae Grube, 1862 (Annelida: Polychaeta) from the Hawaiian Islands with description of two new species. Zootaxa 3581: 1-52

Malmgren AC (1865 [1864]) Nordiska hafs-annulater. Öfversigt Kongl Vetenskaps-Akademiens Förhandlingar 21: 51-110

McCammon JA, Stull JK (1978) A new genus and species of Capitellidae (Polychaeta) from California. Bull South Calif Acad Sci 77: 40-43

McDonald KA, Collin R, Lesoway MP (2014) Poecilogony in the caenogastropod Calyptraea lichen (Mollusca: Gastropoda). Invertebr Biol 133: 213-220

Méndez N, Linke-Gamenick I, Forbes VE, Baird DJ (2001) Sediment processing in Capitella spp. (Polychaeta: Capitellidae): strainspecific differences and effects of the organic toxicant fluoranthene. Mar Biol 138: 311-319

Nakaoka M, Mukai H, Chunhabundit S (2002) Impacts of dugong foraging on benthic animal communities in a Thailand seagrass bed. Ecol Res 17: 625-638

Omena E, Creed JC (2004). Polychaete fauna of seagrass beds (Halodule wrightii Ascherson) along the coast of Rio de Janeiro (southeast Brazil). Mar Ecol 25: 273-288

Papageorgiou N, Arvanitidis C, Eleftheriou A (2006) Multicausal encironental secerity: a flexible framework for microtidal sandy beaches and the role of polychaetes as an indicator taxon. Estuar Coast Shelf Sci 70: 643-653

Paul C, Halanych KM, Tiedemann R, Bleidorn C (2010) Molecules reject an opheliid affinity for Travisia (Annelida). Syst Biodivers 8: $507-512$

Petersen ME (1999) Reproduction and development in Cirratulidae (Annelida: Polychaeta). Hydrobiologia 402: 107-128

Piltz FM (1977) A new genus and species of polychaete (family Capitellidae) from Southern California. Bull Calif Acad Sci 76: $57-60$

Quatrefages A de (1866 [1865]) Histoire naturelle des annelés marins et d'eau douce. Annélides et Géphyriens, Tome Second, Deuxième Partie. Librarie Encyclopédique de Roset, Paris

Rambaut A, Suchard MA, Xie D, Drummond AJ (2014) Tracer v1.6 at http://beast.bio.ed.ac.uk/Tracer on 2018-4-26

Read G (2010) Capitellidae Grube, 1862. In "World Polychaeta Database" Ed by G Read, K Fauchald, accessed through: World Register of Marine Species at http://www.marinespecies.org/ aphia. php? $p=$ taxdetails\&id $=921$ on 2018-1-16

Reish DJ (1955) The relation of polychaetous annelids to harbor pollution. Public Health Rep 70: 1168-1174

Ronquist F, Huelsenbeck JP (2003) MrBayes 3: Bayesian phyloge- netic inference under mixed models. Bioinformatics 19: 15721574

Rouse GW, Fauchald K (1997) Cladistics and polychaetes. Zool Scripta 26: 139-204

Rouse GW, Pleijel F (2001) Polychaetes. Oxford University Press, New York

Rousset V, Pleijel F, Rouse GW, Erséus C, Siddall ME (2007) A molecular phylogeny of annelids. Cladistics 23: 41-63

Rozen S, Skaletsky HJ (2000) Primer3 on the WWW for general users and for biologist programmers. In "Bioinformatics Methods and Protocols: Methods in Molecular Biology" Ed by S Krawetz, S Misener, Humana Press, New York, pp 365-386

Rullier F, Amourex L (1979) Campagne de la Calypso au large des côtes Atlantiques de l'Amérique du Sud (1961-1962). I. 33. Annélides Polychètes. Ann Inst Oceanogr 55: 145-206

Seaver EC (2016) Annelida models I: Capitella teleta. Curr Opin Genet Dev 39: 35-41

Seaver EC, Yamaguchi E, Richards GS, Meyer NP (2012) Expression of the pair-rule gene homologs, runt, Pax3/7, evenskipped-1 and even-skipped-2 during larval and juvenile development of the polychaete annelid Capitella teleta does not support a role in segmentation. EvoDevo 3: 8

Siddall ME, Apakupakul K, Burreson EM, Coates KA, Erséus C, Gelder SR, et al. (2001) Validating livanow: molecular data agree that leeches, branchiobdellidans and Acanthobdella peledina form a monophyletic group of oligochaetes. Mol Phylogenet Evol 21: 346-351

Silva CF, Shimabukuro M, Alfaro-Lucas JM, Fujiwara Y, Sumida PYG, Amaral ACZ (2016) A new Capitella polychaete worm (Annelida: Capitellidae) living inside whale bones in the abyssal South Atlantic. Deep-Sea Res Part I Oceanogr Res Pap 108: 23-31

Stamatakis A (2014) RAxML version 8: a tool for phylogenetic analysis and post-analysis of large phylogenies. Bioinformatics 30 : 1312-1313

Struck TH, Purschke G (2005) The sister group relationship of Aeolosomatidae and Potamodrilidae (Annelida: "Polychaeta")-a molecular phylogenetic approach based on 18S rDNA and cytochrome oxidase I. Zool Anz 243: 281-293

Struck TH, Schult N, Kusen T, Hickman E, Bleidorn C, McHugh D, et al. (2007) Annelida phylogeny and the status of Sipuncula and Echiura. BMC Evol Biol 7: 57

Struck TH, Paul C, Hill N, Hartmann S, Hösel C, Kube M, et al. (2011) Phylogenomic analyses unravel annelid evolution. Nature 471: 95-98

Struck TH, Golombek A, Weigert A, Franke FA, Westheide W, Purschke G, et al. (2015) The evolution of annelids reveals two adaptive routes to the interstitial realm. Curr Biol 25: 19931999

Sumida PYG, Alfaro-Lucas JM, Shimabukuro M, Kitazato H, Perez JAA, Soares-Gomes A, et al. (2016) Deep-sea whale fall fauna from Atlantic resembles that of the Pacific Ocean. Sci Rep 6: 22139

Sundberg P (1993) Phylogeny, natural groups and nemertean classification. Hydrobiologia 266: 103-113

Sundberg P, Pleijel F (1994) Phylogenetic classification and the definition of taxon names. Zool Scripta 23: 19-25

Tamura K, Peterson D, Peterson N, Stecher G, Nei M, Kumer S (2011) MEGA5: molecular evolutionary genetic analysis using maximum likelihood, evolutionary distance, and maximum parsimony methods. Mol Biol Evol 28: 2731-2739

Tanaka M, Kon T, Nishikawa T (2014) Unraveling a 70-year-old taxonomic puzzle: redefining the genus Ikedosoma (Annelida: Echiura) on the basis of morphological and molecular analyses. Zool Sci 31: 849-861

Tanner JE (2005) Edge effects on fauna in fragmented seagrass meadows. Austral Ecolo 30: 210-218 
Tavaré S (1986) Some probabilistic and statistical problems in the analysis of DNA sequences. Lectures Math Life Sci 17: 57-86

Tomioka S, Suda Y, Kamo T, Ohtomi J, Nishi R, Tanaka R, et al. (2012) Polychaete worms in intertidal zone of an open sandy shore at Fukiagehama, Kagoshima Prefecture, southern Japan. J Natl Fish Univ 61: 65-74 (in Japanese with English abstract)

Tomioka S, Hiruta SF, Kajihara H (2013) Description of Mediomastus opertaculeus sp. nov. (Annelida: Capitellidae) from Hokkaido, northern Japan. Spec Div 18: 105-110

Tomioka S, Kondoh T, Sato-Okoshi W, Ito K, Kakui K, Kajihara H (2016) Cosmopolitan or cryptic species? A case study of Capitella teleta (Annelida: Capitellidae). Zool Sci 33: 545-554

Tsutsumi H (1987) Population dynamics of Capitella capitata (Polychaeta; Capitellidae) in an organically polluted cove. Mar Ecol Prog Ser 36: 139-149

Tsutsumi H (2005) Production of planktonic and non-planktonic larvae in a single brood of Capitella sp. I and its implications for population persistence in disturbed environment due to organic enrichment of the sediments. Benthos Res 60: 17-24

Tsutsumi H, Kinoshita K, Srithongouthai S, Sato A, Nagata S, Inoue A, et al. (2005) Treatment of the organically enriched sediment below the fish farm with the biological activities of artificially mass-cultured colonies of a small deposit feeding polychaete, Capitella sp. I. Benthos Res 60: 25-38

Vedetti JE, Trowbridge CD, Krug PJ (2012) Poecilogony and population genetic structure in Elysia pusilla (Heterobranchia: Sacoglossa), and reproductive data for five sacoglossans that express dimorphisms in larval development. Integr Comp Biol 52: $138-150$

Warren LM (1991) Problems in capitellid taxonomy. The genera Capitella, Capitomastus and Capitellides (Polychaeta). Ophelia Suppl 5: 275-282

Warren LM, Parker M (1994) Pseudonotomastus southerni gen. nov. sp. nov., a new capitellid from the Celtic Sea. Mém Mus Natl Hist Nat Sér. A 162: 299-306

Weigert A, Helm C, Meyer M, Nickel B, Arendt D, Hausdorf B, et al. (2014) Illuminating the base of the annelid tree using transcriptomics. Mol Biol Evol 31: 1391-1401

Yamaguchi S, Endo K (2003) Molecular phylogeny of Ostracoda (Crustacea) inferred from 18S ribosomal DNA sequences: implication for its origin and diversification. Mar Biol 143: 23-38

Zwickl DJ, Hillis DM (2002) Increased taxon sampling greatly reduces phylogenetic error. Syst Biol 51: 588-598

(Received January 17, 2018 / Accepted May 5, 2018) 